\title{
RELIGIOSIDADES NA RURALIDADE AMAZÔNICA
}

Jaqueline Pereira de Sousa ${ }^{1}$

\section{Introdução}

A partir do vai e vem das redes, inicia-se a sinestésica viagem da região metropolitana da capital do Estado do Pará, Belém - com duração entre doze e quatorze horas ao bel-prazer da regência das águas do Rio Guamá - até o município de Breves, arquipélago do Marajó, em especial, à comunidade rural à beira do rio Tauau, Santa Luzia. Esse artigo permeia pelas experiências ruralizadas de acordo com as abordagens das religiosidades vividas.

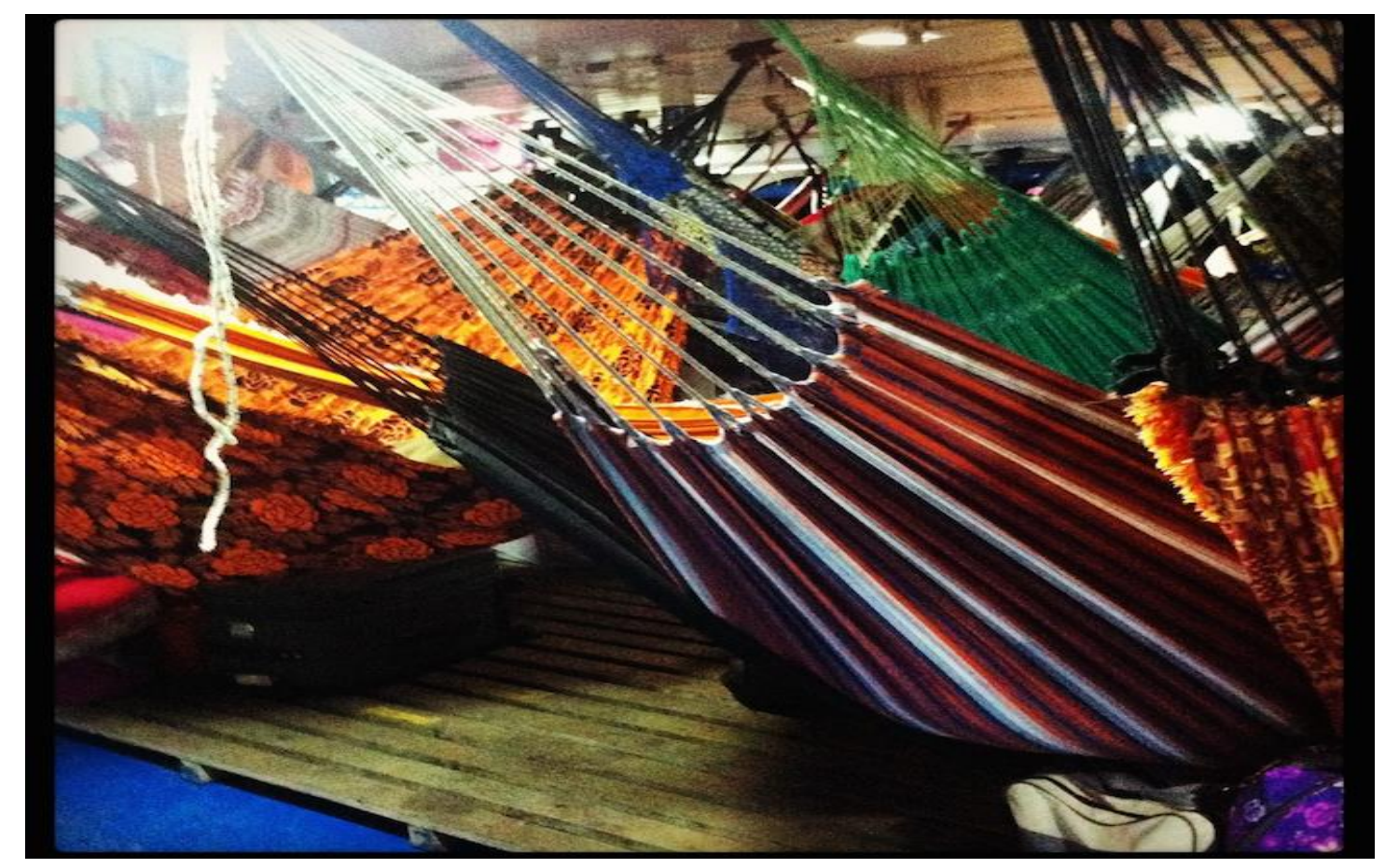

O emaranhado de redes distribuídos pelos três andares do navio.

Apesar de a população habitar a área em questão, a nomeação Santa Luzia é fundada a partir de um possível conflito da religião católica que, de certa forma, traz a reflexão de uma "análise situacional" (Gluckman, 2010): para participar dos ritos religiosos previstos no catolicismo, em especial, os batizados, os moradores da margem

\footnotetext{
${ }^{1}$ Universidade Federal do Pará, Brasil.
} 
do rio Tauau, se dirigiam para a localidade mais próxima que possuía a igreja Nossa Senhora do Perpétuo Socorro. Certo dia, o padre da paróquia se negou a batizar uma das crianças, alegando a ausência dos moradores nos eventos realizados pela igreja Nossa Senhora do Perpétuo Socorro, corriqueiramente.

Ao desqualificar a devoção da comunidade da beira do rio Tauau, o padre provoca um incentivo do mito de fundação: a partir de então, os moradores denominam sua comunidade como Santa Luzia, padroeira dos olhos doentes, comemorando os pedidos recebidos em um festejo que se inicia no dia 12 de dezembro e se estende por uma semana de festividade.
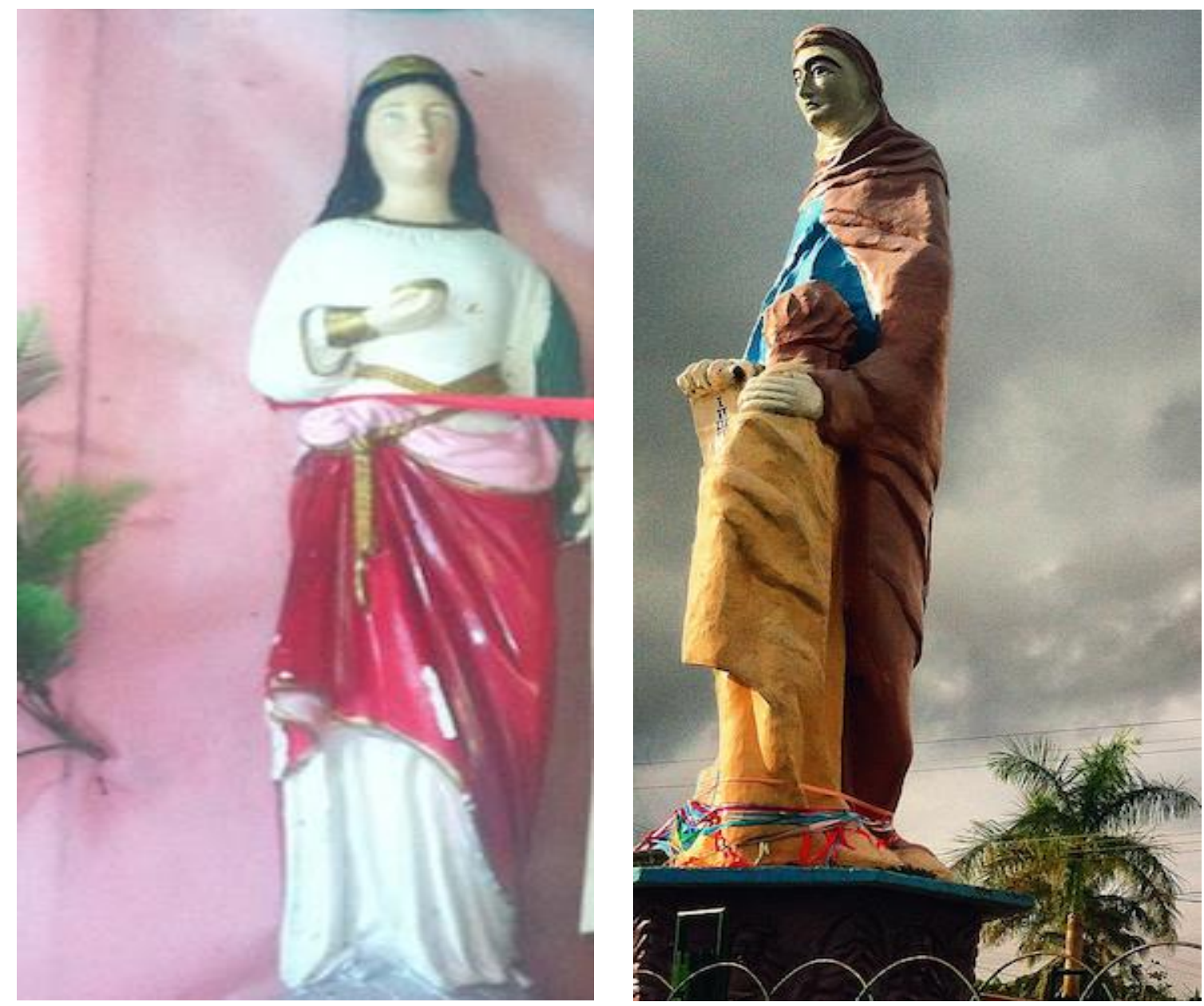

À esquerda, a pequena imagem de Santa Luzia, na capela da comunidade que leva seu nome. À direita, a grandiosa imagem de Sant'Ana que recepciona os que chegam em Breves: fitas que abraçam-nas. 
Aproximando-se da técnica de pesquisa trazida pelo antropólogo Max Gluckman, que analisou a inauguração de uma ponte na Zululândia e, que, apesar do evento durar um único dia, o autor conseguiu enxergar uma diversidade de elementos que perduram a sociedade Zulu, desde seus conflitos e suas convergências.

\begin{abstract}
A partir das situações sociais e de suas inter-relações em uma sociedade particular, podem-se abstrair a estrutura social, as relações sociais, as instituições etc. daquela sociedade. Por meio dessas e de novas situações, o antropólogo deve verificar a validade de suas generalizações (Gluckman, 2010: 239).
\end{abstract}

Através de um recorte situacional da experiência emergida mediado nas (con)vivências com moradores da comunidade rural de Santa Luzia, que se utiliza de um evento social, a fundação da Igreja Santa Luzia (no interior de Breves) nas narrativas ressurgidas no encontro dos discursos construídos, ao contarem a história de sua comunidade atrelada à imagem da Santa Luzia,representante da devoção católica, trazem consigo uma diversidade de elementos da pajelança rural (Maués, 2002) vivenciada na Amazônia e percebida entrelaçada à pluralidade do catolicismo, chamando a atenção a fala remetida à negação das influências do ritual da pajelança, produzida no forte alcance das religiões pentecostais oriundas das cidades maiores que demonizam as práticas religiosas da cosmologia amazônica.

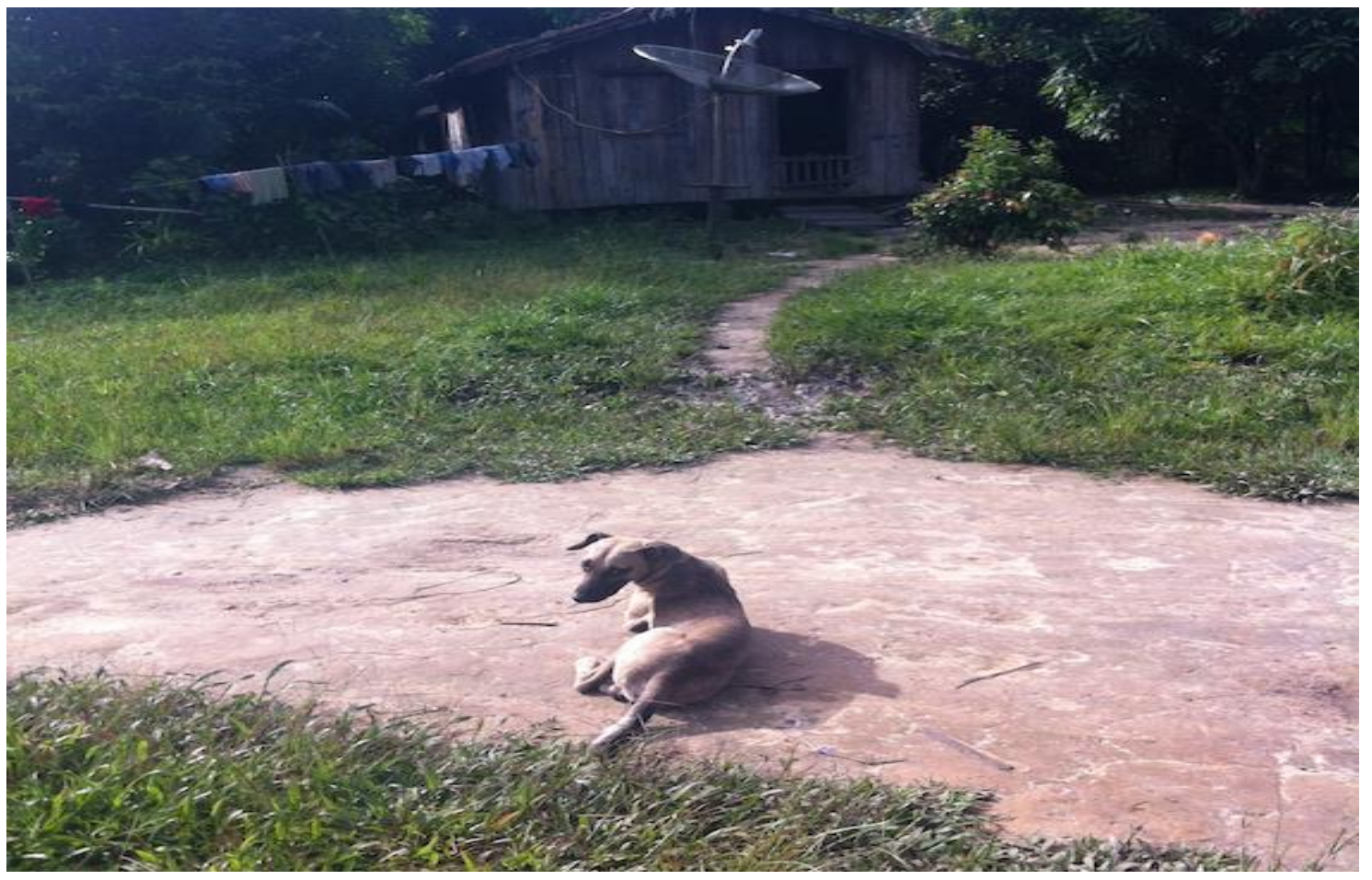

As perceptivas ruralidades e suas dinâmicas: ausência de muros e presença da antena parabólica. O cachorro como alerta tal qual em qualquer âmbito seja ruralizado ou urbanizante. 
Utilizar-se enquanto técnica de pesquisa das narrativas é consolidar uma trajetória estratégica para enlaçar os fatos ocorridos - seja em um passado distanciado ou próximo - no momento atual. Ao expor o passado, o narrador formula uma dinâmica de compreensões em uma performance narrativa (Bauman, 1975; 1986) que contextualiza os episódios sobrevindos das experiências vividas num evento narrativo (Bauman, 1975) capaz de elucidar as questões trazidas nas interrogações do pesquisador/ouvinte.

A narrativa originada dessa convivência com os moradores da comunidade de Santa Luzia se concentra na fala de um casal: Seu Manéu e Dona Rosani, que ao narrar o cotidiano dos seus conhecimentos e experimentos, contribuíram para a feitura de uma breve apreciação acerca das religiosidades amazônicas.

Curupirão, caruara, rompe-mato, incorporações, caboclos, feitiçaria, corrente, encantados, assentamento, quebranto... palavras que possuem um sentido na leitura da cosmologia amazônica e que apareceram durante a visita à casa de Seu Manéu e Dona Rosane ao mesmo tempo que surgiam na minha ideação as formas de tais criaturas, como se a necessidade da elaboração visual, o que no contexto dos eventos narrados em Santa Luzia,

\footnotetext{
A imagem é de uma ambigüidade paradoxal, se estamos dispostos a esquecer, por um momento, a causalidade técnica respectiva: ela transgride as fronteiras entre dois media opostos por uma diferença radical. E há, finalmente, um corpo cuja imagem vemos duas vezes, na imagem primária da estátua e na imagem secundária da tela: um corpo representado [na estátua] e representando [refletindo]. (Belting, 2005: 78).
}

Esse artigo não segue a linha cronológica e muito menos a ordem das narrações concedidas por Seu Manéu, Dona Rosani e Dona Augusta. Prefere-se utilizar de temáticas para um melhor entendimento do leitor em sua compreensão da abordagem às religiosidades amazônicas ruralizadas e que a imaginação se permita direcionar a ruptura de arestas, em que natureza e cultura se mesclam pelos reflexos.

A cultura da natureza/ a natureza da cultura que se evidenciam por meio das dinamicidades atravessadas pelo ruralizado, neste trabalho de campo, concebe uma ampliação do olhar etnográfico, mesmo com os esboços das leituras, se faz necessário um prolongamento dos livros às narrativas extraordinárias. O devir antropológico que não se esgota em categorizações; porém apreende por visagens desenhadas pelas teorias alcançadas pela prática etnográfica. 


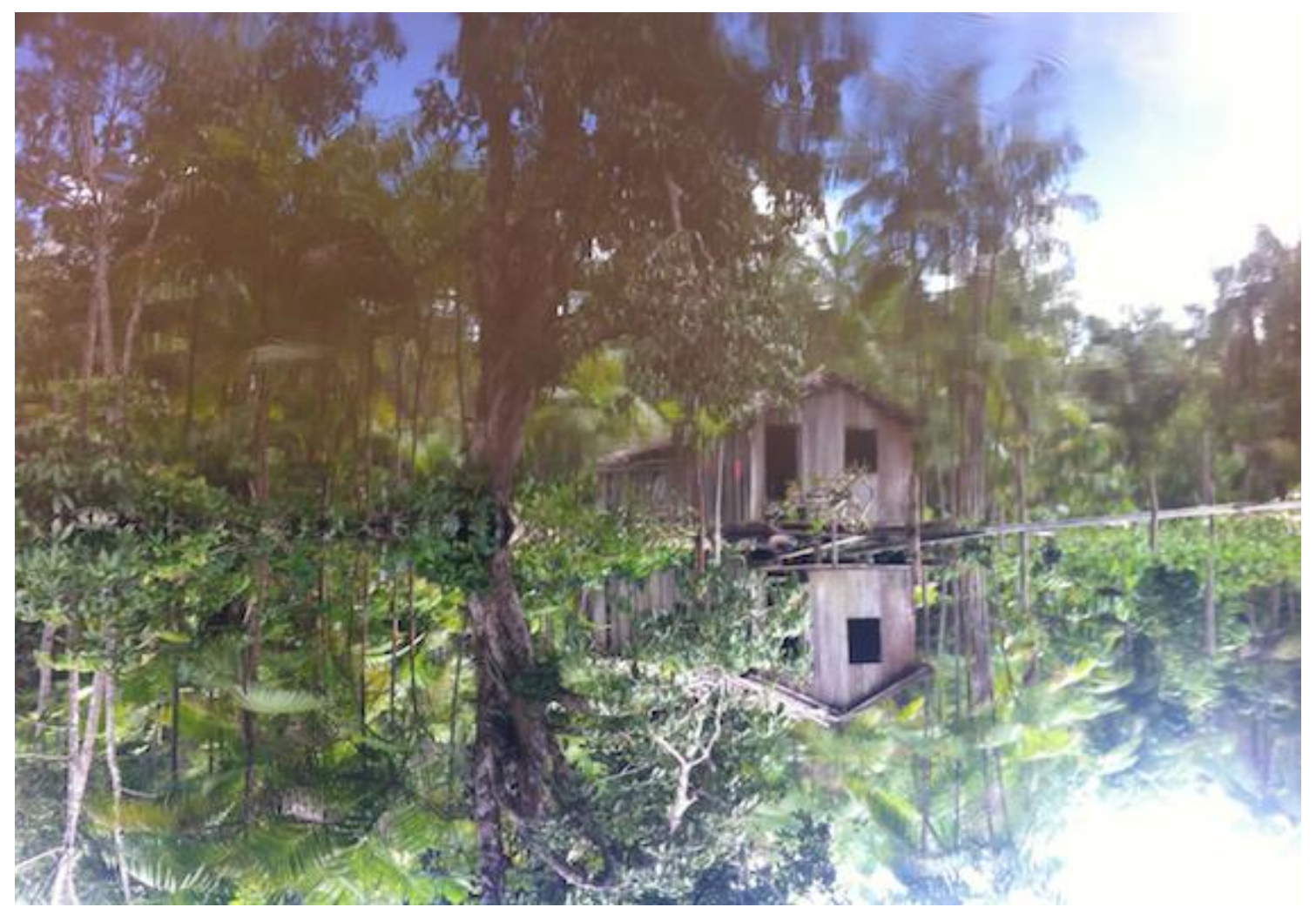

O verso e o inverso: qual o limiar que diferencia o reflexo das imagens?

\section{Coisa do mato? A iniciação do Pajé e a negação da pajelança}

Ao iniciar o diálogo com Seu Manéu, o representante da comunidade e reconhecido como pajé/rezador/benzedor dos moradores de Santa Luzia, é perceptível o esforço que ele faz para não ser designado de pajé, deixando claro que as orações que realiza nas curas vieram dos ensinamentos da sua igreja, no caso a católica: "não tem oração diferente, não". Porém, é comum em uma grande maioria de entrevistas que o narrador já tenha calculado os seus dizeres acerca do que imagina ser indagado. E nesse caso, marcar sua presença totalmente no catolicismo vai se esvaindo nos primeiros minutos da conversa, quando começa a falar da sua clientela e das doenças que são trazidas para que ele as cure. “... De lá pra cá, as coisas que a gente provoca mais nas crianças é esse negócio de malineza de bicho; essas coisas que podem está malinando pela água..."2

\footnotetext{
${ }^{2}$ Como recurso de escrita, evita-se neste ensaio reproduzir os erros gramaticais considerados insignificantes para a compreensão da fala dos interlocutores, como, por exemplo, a ausência de plurais
} 
Seu Manéu inicia a desconstrução da totalidade católica nas suas práticas de cura. Ao inserir o elemento "bicho" e "água", o narrador faz com que a inserção da cosmologia amazônica insurja na sua própria feitura com benzedor. "Esse negócio meu é um dom, eu acho. Eu já trouxe esse dom desde a nascença..."

Nesse momento, Dona Rosani que estava sentada no chão, observando o marido sentado na mesa da entrada da casa, o interrompe dizendo "foi também através da tua tia," Seu Manéu faz um gesto de desaprovação e um sonoro "rum" para que a esposa não se intrometa. Visivelmente chateada, vai procurar lenha para o café.

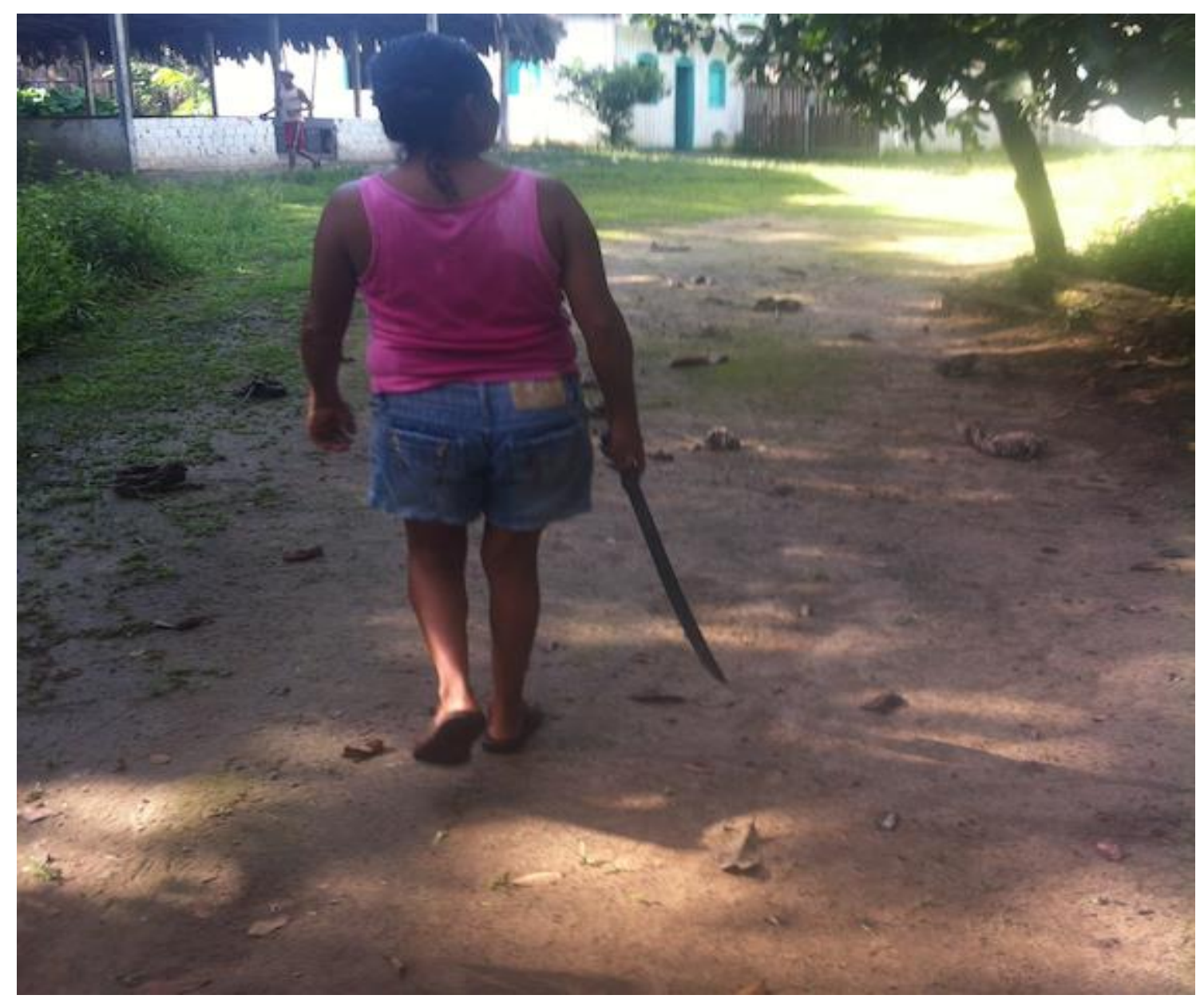

Dona Rosani e seu inseparável facão para derrubar frutos, cortar galhos que atrapalhem sua travessia e, principalmente, cortar a lenha.

"Esse dom eu aprendi na igreja. Eu fui dirigente durante quatorze anos na nossa comunidade e, com essas orações, eu faço nas crianças [...] a gente vê a criança e sente e aí eu faço a oração e, quando a gente faz essas coisas, vai da fé da pessoa é porque

ou a coloquialidade, visto que é um erro corriqueiro que pode ser cometido por qualquer pessoa, independente de sua formação acadêmica. 
muito das vezes, eu tenho prestado atenção nas pessoas, tem muitos que vem e não vem com força, e aí eu faço meu caqueado e não dá certo, porque a pessoa também não crê”.

Seu Manéu desmerece os que foram iniciados em suas práticas mágicas religiosas: "tem uns aí que rezam, mas isso não é dom! Isso aí eles já aprendem é uns com os outros".

A constância da "fé", "força" e do "crer" revela-se com presenças da eficiência para a contemplação da cura. A literatura antropológica explora esse fenômeno de forma ampla, nomeando de eficácia simbólica. A partir do "ato mágico" de Mauss (2003), o trabalho ritual do caqueado do Seu Manéu, se encaixariam no que o autor categorizou como "os ritos orais mágicos" e dependem que exista uma interação da credibilidade entre o "mágico" e o "público", deixando claro que "a crença do mágico e a do público não são duas coisas diferentes; a primeira é reflexo da segunda, já que a simulação do mágico só é possível em razão da credulidade pública” (Mauss, 2003: 131).

Ao retornar ao assunto das malinezas de bicho, Seu Manéu sinonimiza ao mal olhado, não se referiu às pessoas, mas aos seres não humanos: "porque as coisas más se viram em qualquer coisa, até num peixe normal elas se viram pra fazer malineza. E às vezes ele [o ser humano] entra na água de corpo aberto. Às vezes ele [o não humano; o bicho] tira a sombra da criança. E no mato é a mesma coisa! E na oração que a gente faz que se descobre o que é, tocado por Deus e o coração se enche...”

As curas também se dão através dos remédios "da terra", como frisou Seu Manéu, como a defumação, que é feita com coisas "fedorentas" para afastar o mal. O material utilizado na defumação conta com chifre de boi preto, chifre de carneiro, pano preto, folha de limão e o pó do café. A fumaça envolve o doente e, ao suar, ele elimina os males, "e se ele tem muita fé", enfatiza dona Rosani, "é rapidinho".

Além da oração, o sumo do hortelã serve para tirar o quebranto da criança. Seu Manéu espreme num pano e espalha na criança doente.

A sua trajetória de vida é marcada por eventos que permeiam à cosmologia amazônica, confessando que, antes de nascer, chorou na barriga de sua mãe grávida, que na crença popular, sinaliza o nascimento de uma criança com poderes espirituais.

"Numa viagem, minha mãe contava sempre, ela sentiu que eu murmurei dentro dela. Isso daí minha avó me contou. Minha mãe morreu eu tinha dois anos. Fui criado pelo meu pai e pela minha avó. E quando a gente tem esse negócio desse dom; quando a gente é criança e que não é assentado que nem o pessoal fala. É o assentamento da 
pessoa. E quando não está assentado, as coisas tão brabas. E quando eu completei 30 anos é que começou e aí que eu fui com minha tia, lá de Breves, ela me deu um passe e disse que eu ia ser um benzedor e que não tinha jeito."

A palavra assento tem sua origem configurada nas religiões afro-brasileiras, correspondendo ao altar do santo, em que são depositados alimentos e direcionados os pedidos à entidade: “o assentamento é a representação material do orixá, o lugar onde sua energia é fixada, assentada. Fixar o orixá significa 'prender sua energia' numa pedra (otá) e colocá-la num alguidar junto a outros elementos mágicos e louças" (Amaral, 2001: p. 4).

No candomblé, o verbo assentar refere-se ao próprio ritual de iniciação na religião:

\begin{abstract}
$\mathrm{Na}$ iniciação, diz-se que o filho-de-santo "assenta" seu Olori. Isto quer dizer que o pai-de-santo fixa, através de sacrifícios rituais, o orixá na cabeça do filho. Ao longo do tempo este terá seus seis outros orixás do carrego sucessivamente assentados em cerimônias designadas como "obrigações" e que acontecem com um, três, cinco, sete, quatorze e vinte e um anos de iniciação. A cada obrigação um orixá é assentado, de modo que após vinte e um anos de iniciado um filho-de-santo tem todo seu carrego assentado, tornando-se então um "tata" (Goldman, 1987: 90).
\end{abstract}

Seu Manéu denuncia os benzedores que estão ligados "às coisas malignas; ao que não presta: é um tal de tranca rua, de pomba gira e daí a benzeção desses aí, não servem para os filhos". Só que, mesmo categorizando negativamente as práticas relacionadas (aparentemente) às religiões afro-brasileiras, se contradiz e menciona o primeiro trabalho que fez para uma filha, a Lucilene, que se apaixonou por um rapaz João dos Anjos, que morava em Breves, e depois de pouco tempo, ele faleceu. Lucilene adoeceu de tanta falta que sentia do namorado, até que Seu Manéu a benzeu e descobriu que tinha um "espírito mal dentro dela": era o espírito de João dos Anjos. E o remédio foi espinho de murumuru e a defumação de coisas fedorentas, incluindo pneu velho e pelo de preguiça. A finalização do ritual se deu com o banho também fedorento com casca de najarana, casca de buiuçu, pelo de mucuracaá que servem para expulsar o espírito que se apossou do corpo da amada.

Talvez essa existente ligação entre as religiões afro-brasileiras, religião católica e religiões indígenas, represente, de certa forma, o catolicismo plural, que numa incursão pelo catolicismo popular e se espalha por determinantes de crenças e saberes dos interlocutores marajoaras, que mesmo rodeado de práticas das religiões afro-brasileiras e indígenas, consideram-se adeptos e representantes do catolicismo, construindo igrejas 
para seus santos padroeiros e, em devoção, mantendo em funcionamento da igreja, que muitas vezes, o padre não participa, já que essas comunidades se encontram nos espaços ruralizados distantes das grandes cidades.

Mesmo assim, os devotos mantêm-se convictos na genuinidade pura de suas crenças, pois:

Ao se reconhecerem indiscutivelmente como católicos, e no horizonte, subalternos à palavra do padre e ao domínio da Igreja, os sacerdotes populares, ao mesmo tempo, negam a legitimidade e a existência possível de uma igreja popular e paralela, na medida em que reproduzem um sistema religioso católico, comunitário e relativamente autônomo, nos limites da classe e do espaço camponês (Brandão, 1980: 122).

Seu Manéu, apesar de auto identificar-se como antigo dirigente da comunidade católica, benzedor, roceiro e carpinteiro, é perceptível em sua narrativa a importância da pajelança, já que "esse negócio de feitiçaria, tudo isso eu descubro. Agora, esse negócio de umbanda que eles falam, isso eu não dou conta, não! Aí eu só benzo a pessoa, e quando eu descubro o que é, eu mando procurar outro. Aí tem que ir em Breves, porque aqui não tem. No tempo que minha tia era viva, ela fazia tudo".

A pajelança que reúne todo um complexo de práticas mágicas e baseia-se no poder de determinados indivíduos, os pajés, sobre as diferentes classes de sobrenaturais, que utilizam para a cura de doenças e para a feitiçaria; e o uso de rezas ou fórmulas mágicas para uma infinidade de propósitos (Galvão, 1976: 3).

Então, das muitas histórias sobre os processos de cura e das doenças invisíveis, surge a história da caruara...

\footnotetext{
"A caruara é feita do galho de pau. É um bicho perigoso que se flechar na pessoa, que seja venenosa, ela afeta muito o corpo da pessoa, só que na carne da pessoa não aparece, mas dá muita dor. Ela flecha de longe a pessoa. Se a pessoa passar do lado dela, a pessoa não enxerga ela, porque ela é da qualidade de um serrado seco; tipo um galhinho de pau. E, dessas flechadas, fica tipo um esporão dentro da gente, e se a pessoa não se cuidar nem se tratar, é arriscado... quando não mata, aleija!"
}

Seu Manéu confessa que às vezes consegue tirar a caruara, outras vezes não.

Antes dos trinta anos, isto é, antes de ser iniciado pela tia benzedora, ele via visagem, mas ele não tinha medo, pois o que sinaliza a visagem ser ruim é o arrepio na pele, que raramente Seu Manéu sentia, até que um dia...

"eu estava deitado, quase cochilando, umas sete horas da noite, aí pra mim, a gente estava nessa igreja aqui [referindo-se à Igreja de Santa Luzia] e tinha uma vela 
acesa na minha frente e um monte de gente andando por lá, e na minha visão, veio um homem que era conhecido meu, mas depois eu achava que não era meu conhecido, mas mesmo assim me convidou para olhar naquele - que estava tão bonito, e eu só fiz me levantar da rede e já ia no rumo da claridade. Aí que ela [a esposa] chamou pelo meu nome e, quando me espantei, eu já estava era no chão. Se não fosse ela me chamar, eu tinha ido embora. Ele tinha me levado".

Dona Rosani menciona que sua atuação se deveu à experiência com o pai, que também era benzedor e incorpora os caboclos e os encantados. Seu Benedito, conhecido como Seu Coroca, foi o fundador da comunidade Santa Luzia e também como seu Manéu, é representante de uma religiosidade particular aos trajetos amazônicos: trata-se da pajelança cabocla, que de acordo com Maués (2002) ganha uma outra perspectiva:

Essa forma de pajelança [cabocla ou rural], que não se confunde com a pajelança indígena, pode ser considerada uma forma de xamanismo, já que é uma prática ritual voltada, sobretudo, para a cura de doenças, através da ação de pajés ou curadores, que agem sobre os doentes enquanto estão incorporados por entidades sobrenaturais — os encantados ou caruanas — que são vistos como os "verdadeiros" agentes de cura. Entretanto, essa prática não possui autonomia ou identidade própria, como outras manifestações religiosas (Maués, 2002: 54).

Ele permaneceu por muito tempo adoentado, sentindo tristezas e fraquezas e a solução para seu Manéu foi a iniciação ao ofício de benzedor, através de um trabalho feito pela tia que tinha relação com os encantados e que fazem parte da mesma corrente de Seu Manéu “isso são meus parceiros te perturbando. Tu tem essa corrente e eu acho que a minha corrente é que está na tua. No dia em que eu falecer, tu vai ter que ficar com ela". Profetizou a tia que ainda o questionou "mas tu quer?" e o iniciante "eu quero, pois eu já benzia mas não enxergava os encantados direito." A corrente da tia foi passada para o seu Manéu.

Nesse momento, um dos nove filhos aparece e dona Rosane menciona "esse aqui estava doente", e ao estar envolta às narrativas da pajelança, indago "e o senhor rezou pra saber o que era?", Seu Manéu riu e disse "não, porque eu sabia que era gripe", insisto na pajelança “e que remédio o senhor deu para ele?" "ele tomou multigripe, daqueles que vendem na farmácia." 
Dona Rosani, num descuido pela pausa na fala do marido, protagoniza a narrativa sobre a experiência dela com os encantados, através do pai, seu Benedito, mencionado anteriormente. Ela presenciou várias vezes o pai incorporado por caboclos: o prenúncio se dava através da mudança de temperatura no corpo "fica friazinha" daí, a chegada dos encantados.

Seu Manéu retoma a voz e traz a história dos encantados, dita pela sua avó (ainda viva com 105 anos, na cidade de Breves), de que um rato se apaixonou pela sereia e que acabou levando o ratinho para o fundo das águas "só que essas pessoas encantadas não morrem. Não morreram, pois quando aparecem, é só a sombra deles", descreve Seu Manéu, enfatizando ser uma prática exclusivamente da igreja Católica, com o receio visível de ser confundido com algo que o remeta ao campo das religiões de matrizes indígenas e africanas, vista a afirmação posterior acerca de que "até porque essa lei dos mais velhos; eles não gostam disso, não aceitam.”

No intervalo de uma xícara de café e mais narrativas sobre o cotidiano narrado pelos interlocutores, Seu Manéu revela a herdeira de seu poder xamânico e do seu sogro: sua filha Mariane de nove anos, "enxerga coisas" e possui "todo jeito de benzedora", além do mais, sempre "vê alma sapeca".

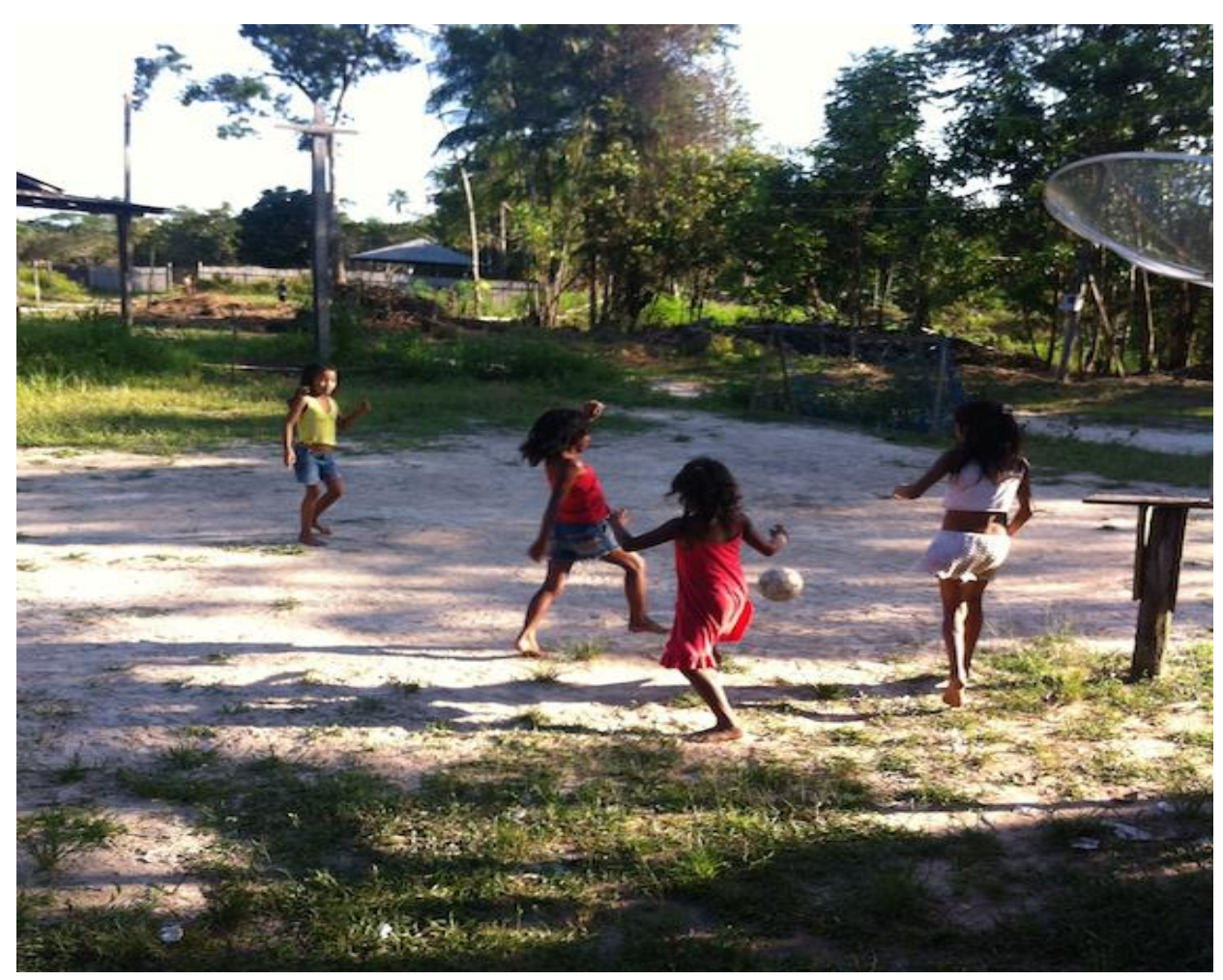

Mariane brinca com suas irmãs no terreiro de sua casa depois de assistirem seu desenho predileto: Monster High. 
A Igreja Católica que, ao avançar dos oceanos pelos séculos XV e XVI, traz consigo suas ideias centrais que se adaptaram aos contextos latino-americanos, através das inserções das religiosidades de outras culturas, sobrevivendo e reforçando seus conceitos em suas práticas. O catolicismo popular é "uma religião voltada para a vida aqui da terra" (Zaluar, 1983: 13).

O que motiva a esclarecer alguns pormenores do catolicismo à brasileira é que, impulsionados e influenciados pelas culturas que cercam uma espécie de "identidade brasileira" - se não cristalizada -, com aspectos que traga algo que nos reconheçamos, tal qual

\begin{abstract}
Nosso velho catolicismo, tão característico, que permite tratar os santos com uma intimidade quase desrespeitosa e que deve parecer estranho às almas verdadeiramente religiosas, provém ainda dos mesmos motivos. A popularidade, entre nós, de uma santa Teresa de Lisieux - Santa Teresinha - resulta muito do caráter intimista que pode adquirir seu culto, culto amável e quase fraterno, que se acomoda mal às cerimônias e suprime as distâncias. (...) foi justamente o nosso culto sem obrigações e sem rigor, intimista e familiar, a que se poderia chamar, com alguma impropriedade, 'democrático', um culto em que se dispensava no fiel todo esforço, toda diligência, toda tirania sobre si mesmo, o que corrompeu, pela base, o nosso sentimento religioso (Holanda, 1969: 149).
\end{abstract}

A pragmática observação feita pelo autor de como o brasileiro repudia as ritualizações, ultrapassa a espera pública dos órgãos estatais e se expande além das relações pessoas-pessoas; alcançando pessoas-sagrado. Essa ligação de familiaridade entre santos e sujeitos, dá um caráter sui generis às formas como o brasileiro lida com a religião. A distância entre o sacro e o indivíduo é significativamente diminuída, para que esse elo seja experienciado de uma maneira mais intensa.

A pluralidade do catolicismo e suas adaptações no cotidiano ganha denominações de acordo com cada contexto cultural. É perceptível que na maioria dos arranjos contextuais o catolicismo popular talvez se mostre mais adequado ao que os interlocutores de Santa Luzia identificam como

\footnotetext{
Um conjunto de crenças e práticas socialmente reconhecidas e partilhadas por um número significativo de católicos que mantém uma independência relativa da hierarquia eclesiástica e dos quadros intelectuais a elas ligados. De um ponto de vista subjetivo, podemos entendê-lo como uma maneira religiosa peculiar de um grupo ou indivíduo viver a sua fé. Num sentido objetivo, trata-se de um sistema religioso centrado no culto aos santos, compreendido dentro de uma lógica contratual de relações interpessoais, e mantido por um corpo difuso de agentes religiosos leigos (Steil, 1997: 94).
} 


\section{A gravidez mágica: o parto do poraquê, do tatu e o velório da criança bicho- preguiça}

"Nós morávamos em cima da água, fazia xixi lá menstruada e acho que nisso, eu engravidei do bicho [o poraquê]. Aí eu fui adoecendo, adoecendo, ficando seca daí eu vim pra casa da mamãe pra ela cuidar de mim. Eu nem lembro mais o remédio que ela fez pra mim..."

A mãe de Dona Rosani, Dona Augusta, chega nesse momento na casa e senta-se timidamente no chão sem se pronunciar ou ser anunciada. E, ao ser indagada sobre qual fora o remédio que curou Dona Rosani das dores provocadas pela gravidez do poraquê, a espetaculosa sabedoria dos povos amazônicas do âmbito natureza/cultura é pronunciada:

"foi chá de chicória com a folha da torna que o finado [?] ensinou e eu fervi. Quando foi perto das seis horas, ela [Rosani] se acocou no banheiro. Oh, parto feio! Saiu aquela cabeçona. Era o poraquê. Só a cabeça! O corpo já tava seco. Foi muito sangue..." Dona Rosani diz que ficou com medo depois dessa gravidez e evita urinar na água durante a menstruação.

Nesse instante, surgem as outras gravidezes mágicas. Narrada na presença do genro, Seu Manéu e das crianças, que por nem um momento estranharam o assunto, o que lembra a descrição de Malinowski e a gravidez das mulheres de Kiriwina (Ilhas Trobriand) pelos espíritos dos mortos, os balomas.

\footnotetext{
La causa real del embarazo es siempre un baloma que se inserta o penetra en el cuerpo de una mujer, y sin cuya existencia ésta no quedaría preñada; todos los niños se hacen o vienen a la existencia (ibubulisi) en Tuma. [...]. Si se pregunta a cualquier hombre, mujer, o incluso a un niño inteligente, se obtendrá siempre esa información (Malinowski, 1993: 89).
}

Porém, convido a narradora para um passeio de barco. Confesso que sentiria mais a vontade conversar esses assuntos sem a presença de homens e crianças. E, em nosso perambular pelo rio calmo com "a água ainda pequena", Dona Augusta continua narrando sobre as experiências da "barrigada de bicho".

A parteira lembra a história da amiga Benoca que "teve duas barrigadas: uma de poraquê e outra de tatu." Benoca engravidou do tatu macho ao preparar a carne desse animal para a alimentação de sua família. A gravidez do poraquê se deu por um banho no rio e ele o "beijando por baixo" - em ambas as situações, Benoca estava menstruada. 
Curiosa sobre o que acontecera com os recém-nascidos, indago sobre seus destinos: o poraquê foi solto na água e o tatu foi morto e jogado fora. Os dois nasceram sem características humanas, sendo assim tratados como animais, mesmo que tenham sido paridos por uma mulher.

Outra história remete à gravidez de bicho-preguiça por Joyce, outra filha de dona Augusta, que entusiasmada, se empodera pelas palavras e pelos gestos : "foi o parto mais perigoso que eu já entrei. Eram três parteiras e quando viram a dificuldade da minha filha, correram tudo! Eu disse 'meu Deus'. Me peguei à Santa Luzia. A igrejinha era ali na beira do rio. As meninas já estavam chorando, aí eu fui pra capela. Me peguei com Santa Luzia e dizia 'se tu fazer que minha filha ter essa criança, embora que seja morto; do jeito que tiver! Eu quero que ela tenha e fique em paz! Ela vai ser dirigente da comunidade uns tempos e vai ser a cantora. E ela foi! Foi dirigente da comunidade por um tempo e foi cantora. E ela dirigia muito bem".

O parto de Joyce foi marcado por sofrimento por nenhuma das parteiras conseguir que a criança "se endireitasse". Ao ver a filha ficando "mofina", dona Augusta tentou puxar a criança quando percebeu que estava colada "parecendo uma saca" com os pés virados pra baixo ao invés da cabeça, como normalmente acontece. Foi preciso ir atrás de uma rabeta (barco a motor) que a levasse para Breves. Dona Augusta embrulhou a filha numa rede, colocando-a na rabeta. Ao passar em frente à Igreja de Santa Luiza (que antes ficava na beira do rio Tauau) a criança "desaprega" e dona Augusta consegue puxar o natimorto: a cabeça era de criança mas os pés e as mãos eram de preguiça. Joyce é levada de volta pra casa enrolada na rede com o filho. A rabeta precisou ser lavada, pois o sangue estava por toda parte. A criança foi velada e no outro dia enterrada no cemitério à beira do rio Tauauzinho, afluente do rio Tauau, onde são enterrados todas da comunidade Santa Luzia e circunvizinhanças.

O consumo da carne de tatu virou tabu alimentar para Joyce. Além do preparo de carne de animais silvestres durante o período menstrual, alerta dona Augusta "ora! Onde já se viu cuidar de caça doente ${ }^{3}$ ?!"

A menstruação, nesse caso, pode ser interpretada como mediador entre o mundo dos espíritos e o mundo dos vivos e a partir dessa conexão são criados os rituais de interdições para que essa mulher menstruada não interfira na vida da comunidade.

\footnotetext{
${ }^{3}$ Menstruação e doença são sinônimos para as mulheres da comunidade Santa Luzia.
} 
As ameaças de ordem natural a que fica exposta a mulher durante a menstruação constituem um importante fator ideológico do grupo, para justificar o comportamento ritualizado que se impõe nesse estado, contribuindo para restringir a sua atuação no sistema social. $\mathrm{O}$ mesmo se pode dizer com relação às ameaças $\mathrm{e}$ proibições de ordem sobrenatural[...]"bichos" ou "encantados-do-fundo", que habitam ou frequentam o mangai, o porto, os rios e igarapés, locais que por isso devem ser evitados pela mulher naquela situação (Motta-Maués, 1994: 116).

Rosani comenta a mudança para uma casa na terra depois da sua gravidez de poraquê. A casa de palafita ${ }^{4}$ trazia o receio de acontecer novamente, ainda mais pelas filhas de Rosani que foram instruídas desde pequenas a não se aproximar do Rio quando estiverem menstruadas.

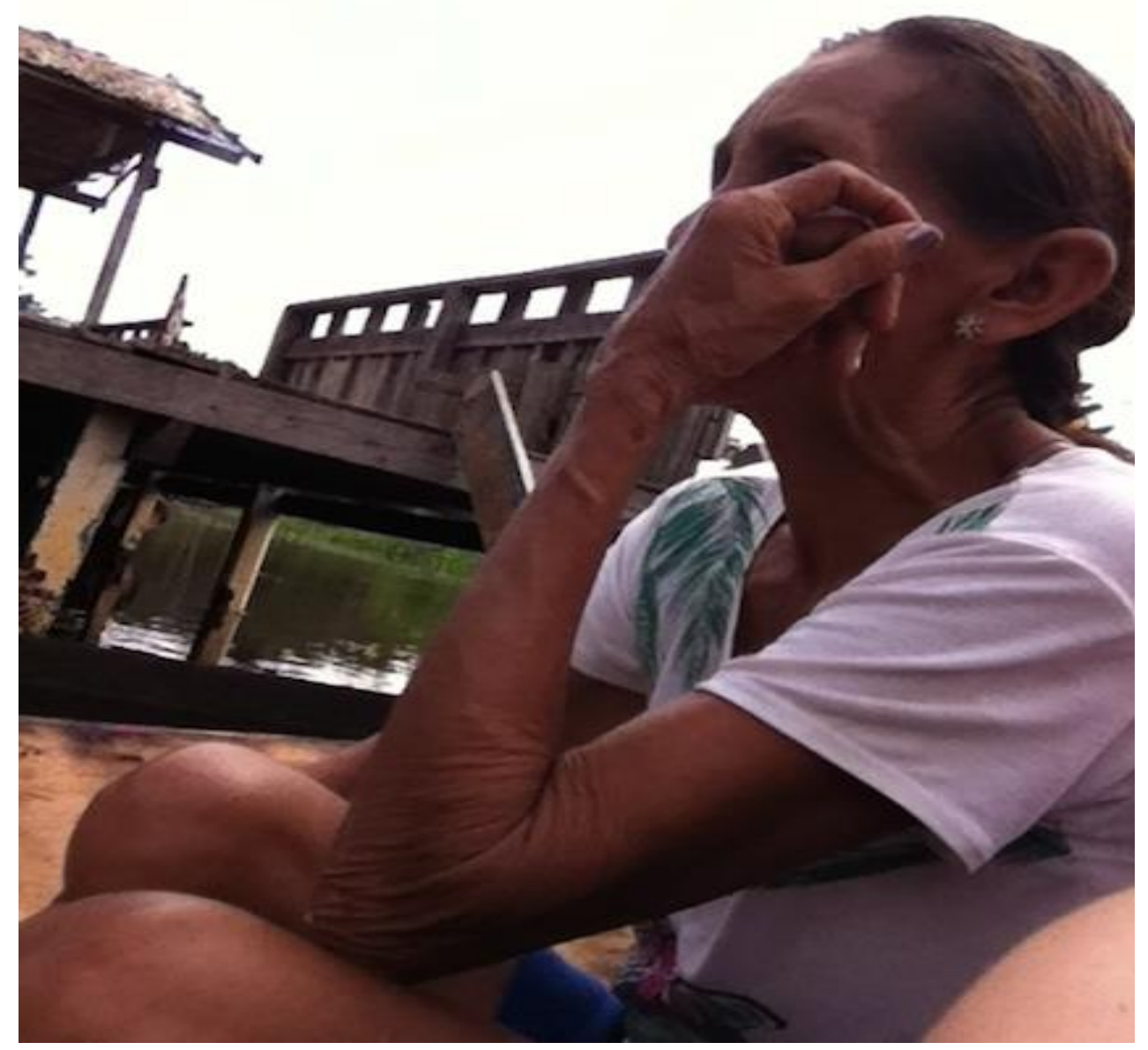

Dona Augusta, à beira do rio Tauau, performatizando as narrativas que aconteceram lá mesmo, no caso do translado de Joyce: o rio, o barco e angústia.

\footnotetext{
${ }^{4}$ Habitação na beira do rio, sustentada por estacadas de madeira fincadas na água.
} 
$\mathrm{Na}$ literatura antropológica existe uma vasta coletânea descrevendo com determinadas sociedades que tem como interdito a menstruação. Desde os escritos evolucionistas como o Ramo de Ouro (Frazer, 1982 [1922]) em que o autor elenca a interdição da mulher durante seu período menstrual devido ao perigo que representam aos objetos e lugares que por elas são contaminados e ao homem, como no exemplo que James Frazer traz sobre o Talmud": "se uma mulher no início de sua menstruação passar entre dois homens, matará com isso a um deles. Se passar entre eles no final da menstruação, apenas fará com que briguem violentamente".

Mary Douglas (1976) elabora os quesitos polarizantes que refletem o puro e o impuro na cultura. Aquilo que é considerado como fora do seu lugar cotidiano, estando em desordem é percebido com perigoso. A mulher menstruada é situada na maioria das sociedades pertencente ao poluído e sujo, sendo assim submetidas aos rituais de interdição e/ou de purificação, como relatado na etnografia realizada por Mary Douglas junto aos Lele de Kasai, no Congo ${ }^{6}$ ao descrever as atribuições impostas à mulher menstruada, impedindo-a de preparar a comida, trabalhar, pescar, relacionar-se sexualmente (causando a impotência do parceiro), atear fogo, etc.: "uma mulher menstruada e na floresta era um perigo para toda a comunidade" (Douglas, 1976: 111).

A menstruação como ocorrência fisiológica na mulher e trazido para o campo da cultura ao adquirir diversas maneiras de se lidar, variando de sociedade para sociedade pela ritualização e, em muitas vezes, como tabu. A menstruação, portanto, além de ser mediadora entre os feitos mágicos e a mulher, pode ser vista como agenciamento entre a natureza e a cultura.

A menstruação, com todos os rituais que a acompanham, torna manifesta a dupla natureza da mulher, como ser cultural e animal ao mesmo tempo. É nessa duplicidade que reside a sua força, pois todos os seres situados na interseção de ordens opostas gozam dos poderes da ambiguidade (Augras, 1989: 41).

Curt Nimuendajú, ao conviver junto com os Tukuna, no Estado do Amazonas, trouxe como percepção os aspectos mágicos da menstruação e o poder devastador em relação aos homens da vulnerabilidade dessas mulheres durante o período. É como se a

\footnotetext{
${ }^{5}$ Livro considerado sagrado pela religião judaica e um dos mais importantes e que, em uma de suas passagens, afirma a sujeira que envolve a menstruação e como o judaísmo considera crianças concebidas durante esse período como bastardas.

${ }^{6}$ Para maiores informações sobre o assunto, cf. Douglas (1963).
} 
natureza (da mulher) em contato com a natureza (floresta) além de diferenciadas, se tornam incompatíveis e nocivas:

The spirits of certain trees such as the kapok-sumahuma (voci'ne), which the Tukuna identify with the curupira of the Neobrazilians have the tendency to wound menstruating women with "arrows," even by day; this is why women do not like to stray far from the house yard while menstruating. Contact with menstrual blood makes a man inefficient (l.g., panemá; T., iejp) in hunting and fishing, and even in other activities .A pepper bath is the most efficacious antidote. (Nimuendajú, 1952: 92)

As condutas culturais - aqui expostas - em relação à menstruação provocam uma reflexão de gênero em que os rituais durante a menstruação estão direcionadas para evitar acontecimentos prejudiciais aos homens, mostrando-se minimizadoras da atuação dessas mulheres, corroborando para a desigualdade na hierarquização do binômio macho x fêmea.

\section{Conclusão}

Esse artigo procurou retratar os eventos narrados (Bauman, 1986) pelos interlocutores da Comunidade Santa Luzia sobre os pertencimentos ruralizantes/ruralizado-se as vivências, muitas vezes, tornaram-se ritualizados durante a exposição de suas falas enquanto performances (Bauman, 1975) dos acontecimentos direcionados às religiosidades praticadas na comunidade rural, apesar de se oficializar como católica, possui a influência das religiões de matriz africana e indígena.

A convivência com três grandes personagens da comunidade tornaram-se o leitmotiv desse artigo. As narrativas de Seu Manéu, Dona Rosani e Dona Augusta entrecruzam as definições acadêmicas da antropologia e são remendadas durante todo texto, fazendo esse entrelaçamento se aproximar ao máximo de uma autoridade etnográfica polifônica (Clifford, 1998). São vozes que desvendam os saberes amazônicos envoltos pela mediação entre os não-humanos.

A ruralização desses espaços se manifesta não só no distanciamento geográfico ou em suas cristalizações conceituais. A ruralidade atravessa os caminhos da natureza adaptando-se ao que o modernizante nos trouxe, como por exemplo, o barco escola, que com a pouca verba destinada (às vezes sim, na maioria das vezes: não) aos moradores em que se encarregam do trajeto casa e escola das crianças de Santa Luzia. 


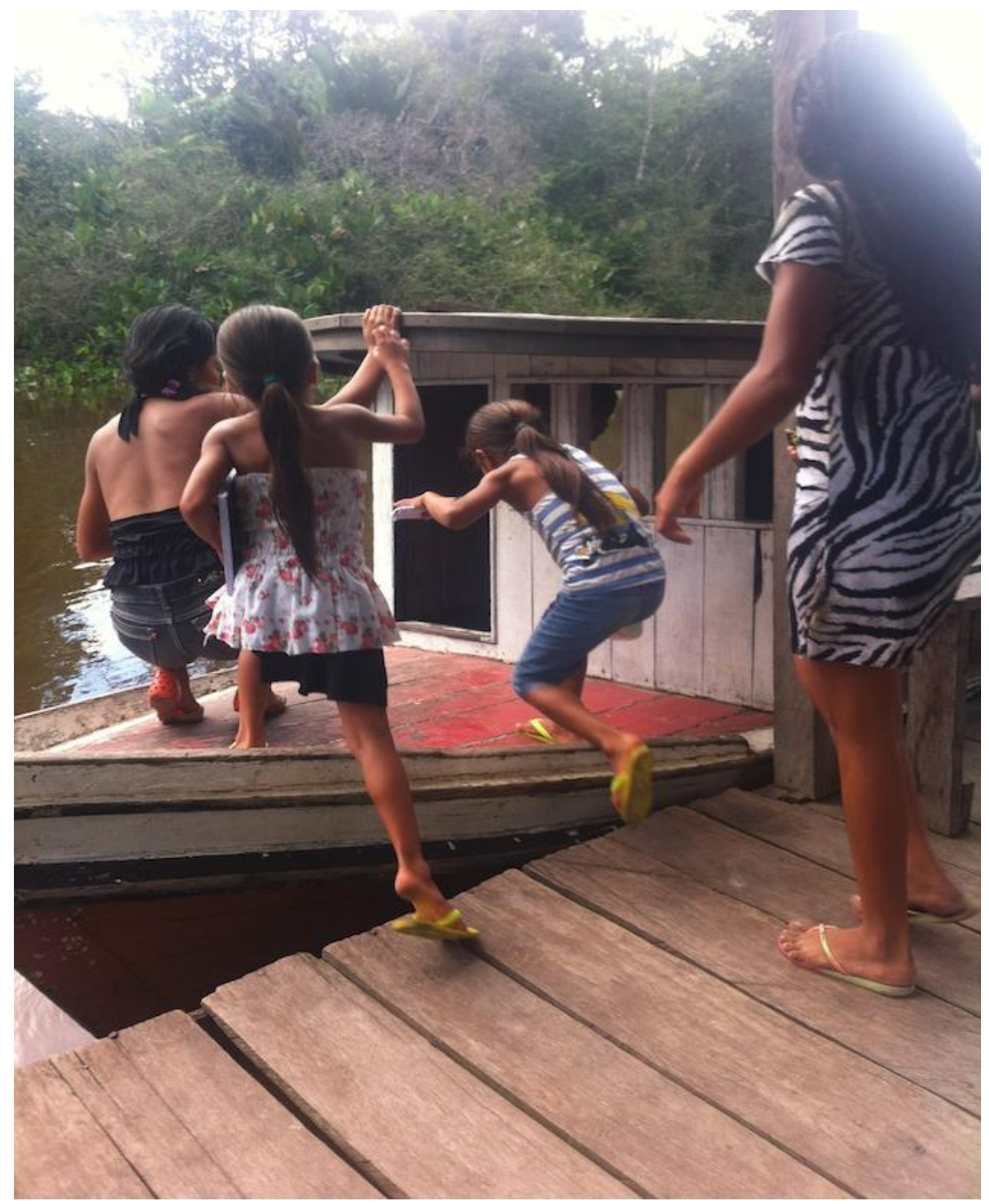

Cadernos na mão, lápis no bolso e graviolas derrubadas durante o recreio. Nesse dia, não houve merenda...

Por fim, ao decorrer de todo o texto é possível observar o diálogo incessante e contínuo da natureza com a cultura nas entrelinhas que se materializam o rural, demonstrando a incapacidade de identificar em determinadas circunstâncias onde inicia a cultura e termina a natureza - lembram da casa e o reflexo por meio do céu e do rio? Talvez porque essa fragmentação entre as duas categorias seja inexistente e, ao mesmo 
tempo, que se consolidam como categorias fortes, firmam-se enquanto definidoras do pertencimento dos interlocutores de Santa Luzia e tal prerrogativa se estende à complexidade rural/urbano amazônico.

A não hierarquização da natureza e da cultura é essencial para a leitura das narrativas aqui incorporadas: o rio, a floresta, os animais, os humanos e os não-humanos se mostram em pé de igualdade, embora o poraquê e o tatu paridos por Benoca tenham sido tratados como animalizados. É importante ressaltar que as gravidezes mágicas fazem parte das narrativas dessa comunidade que ao performatizar essas memórias, humanizam a natureza ao naturalizar a própria cultura.

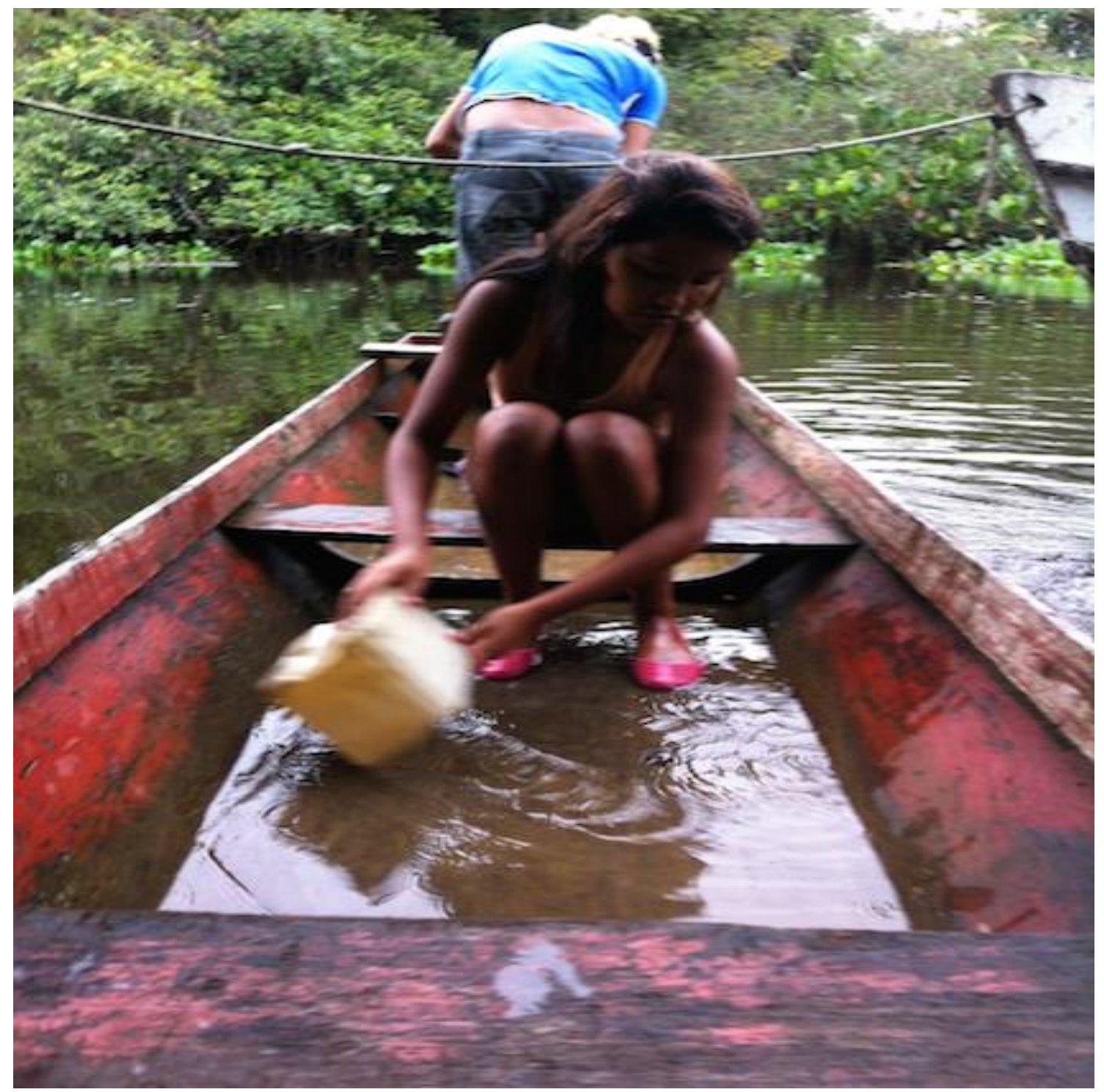

O transitar entre as casas da comunidade se dá pela rabeta e a técnica de retirar a água que teima em ser mais rápida que o balde. 


\section{Referências}

AMARAL, Rita Cássia. A coleção etnográfica de cultura religiosa afro-brasileira do Museu de Arqueologia e Etnologia da Universidade de São Paulo. São Paulo: Revista do Museu de Arqueologia e Etnologia da USP, 2001.

AUGRAS, Monique. O que é tabu. São Paulo: Brasiliense, 1989.

BAUMAN, Richard.Verbal art as performance. American Anthropologist. n. 77, p. 290-311, 1975.

Story, performance and event: contextual studies of oral narrative. Cambridge: Cambridge University Press, 1986.

BELTING, Hans. Por uma antropologia da imagem. Revista Concinnitas, v. 1, n. 8, p. 64-78, 2005.

BRANDÃO, Carlos Rodrigues. Sacerdote de Viola. Petrópolis: Ed. Vozes, 1980.

CLIFFORD, James. Sobre a autoridade etnográfica. In A experiência etnográfica antropologia e literatura no século XX. Rio de Janeiro: Editora UFRJ, 1998, p. 17-62.

DOUGLAS, Mary. Pureza e perigo. São Paulo: Ed. Perspectiva, 1976.

FRAZER, James.O Ramo de Ouro. Rio de Janeiro: LTC, 1982.

GALVÃO, Eduardo. Santos e visagens: um estudo da vida religiosa de Itá, Baixo Amazonas. São Paulo: Ed. Nacional, 1976.

GLUCKMAN, Max. Análise de uma situação social na Zululândia moderna. In: FELDMAN-BIANCO, B. (org.). Antropologia das sociedades contemporâneas métodos. São Paulo: Ed. UNESP, 2010.

GOLDMAN, Márcio. A construção ritual da pessoa: a possessão no candomblé. In: MARCONDES de MOURA, Carlos Eugenio. (Org.). Candomblé: Desvendando Identidades. São Paulo: EMW Editores, 1987.

HOLANDA, Sergio Buarque de. Raizes do Brasil. Rio de Janeiro: José Olympio, 1969.

MALINOWSKY, Bronislau. Magia, Ciencia y Religión. Barcelona: Editorial Planeta de Agostini, 1993.

MAUÉS, Raymundo Haroldo. Catolicismo e xamanismo comparação entre a cura no Movimento Carismático e na pajelança rural amazônica. Ilha Revista de Antropologia, v. 4, n. 2, p. 51-77, 2002.

MAUSS, Marcel. Sociologia e antropologia. São Paulo: Cosac Naify, 2003.

MOTTA-MAUÉS, Maria Angelica. "Lugar de mulher": representações sobre os sexos e práticas médicas na Amazônia (Itapuá/Pará). In: ALVES, P. C.; MINAYO, M. C. S. (Org.). Saúde e doença: um olhar antropológico. Rio de Janeiro: Fiocruz, p. 113-125, 1994.

NIMUENDAJÚ, Curt. The Tukuna. Berkeley and Los Angeles: University of California Press, 1952.

STEIL, Carlos A. et alii. As comunidades de base em questão. São Paulo: Paulinas, 1997.

ZALUAR, Alba. Os Homens de deus. Um estudo dos santos e das festas no catolicismo popular. Rio de Janeiro: Zahar, 1983.

Recebido em: 03/11/2015.

Aprovado em: 21/12/2015. 